\title{
Writing Philippine Cinema, Reading Nic Tiongson
}

Anne Frances N. Sangil

A Reader in Philippine Film: History and Criticism (Chua, Cruz-Lucero, \& Tolentino, 2014) is a collection of essays in honor of film critic and scholar Nicanor G. Tiongson. It is a companion piece to A Reader in Philippine Theater: History and Criticism, also published in the same year. The essays included in the film reader are mostly papers presented at a symposium held in 2011 at the Ateneo de Manila University and the University of the Philippines in honor of Tiongson.

In twelve chapters, this book offers the reader a valuable and in-depth view into several contemporary issues and trends affecting Philippine cinema. The book opens with Rolando B. Tolentino's "Sinema ng Milenyo: Kritisismong Pampelikula, Kritisismong Pambansa." This introduction gives the reader an overview of film criticism and scholarship in the country, and Tolentino's arguments about film aesthetics, film as ideology, and films within social and cultural contexts frame the trajectories taken by the succeeding chapters.

Soledad S. Reyes's "Komiks into Films (1970s and 1980s): Texts as Cultural Practices" looks into the rise and fall of komiks [local comic books] vis-à-vis film adaptations. She situates the komiks adaptations from its roots in literary adaptations during the early days of Philippine cinema and explores how the post-war years saw the rise not just of serialized stories but of screen adaptations of this medium as well. 
Clodulado del Mundo Jr.s "Rody Lacap, Direktor ng Potograpiya: Buhay ang Awtor at Kailangang Buksan Lamang Natin ang Ating mga Mata" highlights the value of the director of photography in filmmaking and the role of Lacap as auteur. This discussion of authorship is followed by "Tunog Lata: Ang Musika ni Teresa Barrozo sa mga Pelikulang Tirador (2007), Kinatay (2009), at Bakal Boys (2009)," as Jema M. Pamintuan gives attention to the value of sound design and music in three selected films all under the expertise of Barrozo as film scorer and musical director. It focuses on the use of steel, tin, and similar metallic instruments in the creation not just of mood but of character within the narrative.

In the same vein, "Burgis Criticism: Karangyaan sa Panahon ng Sigwa sa mga Piling Pelikula ni Danny Zialcita (1980-85)" uses selected films directed by Zialcita to foreground the filmmaker's inclination toward what Renei Patricia Dimla refers to as "sosyal realism." According to Dimla, Zialcita maintains within his cinematic world the bourgeois hegemony over the ruled and continues to limit whatever potential for subversion the latter has, whether in terms of class or sexuality. Dimla argues that Zialcita's films explore the personal and predicable lives of the ruling class with little to no understanding of the realities outside of their gilded cages. Meanwhile, "Ang Diskurso ng Pelikula sa Kolonyalismo at Ikatlong Daigdig" by Jay Jomar F. Quintos discusses how Kidlat Tahimik's Mababangong Bangungot (1977) creates and weaves a complex narrative that illustrates how a film can go against the conventional first-world filmmaking that typifies Hollywood and the West. Following the film's critique of capitalism and neocolonialism, Quintos situates Mababangong Bangungot within the cultural history of Tahimik's notion of nation.

"The Fil-Am Contact, the Politics of Memory, and the Ends of Cinematic Experimentation” by Patrick F. Campos uses John Sayles' Amigo (2011), Camilla Griggers and Sari Dalena's Memories of a Forgotten War (2001), Marlon Fuentes's Bontoc Eulogy (1995), and Raya Martin's Independencia (2009) to contemplate the varied reconstructions of the Philippine-American contact in cinematic and cultural memory. Campos, as he examines the films in relation to their various reconfigurations of history and remembrances, invites, if not involves, the reader in the anxiety of meditating upon the marginalized and mediated memory of the Philippine-American War. He also prompts the reader's own limited (or lack of) personal memory about cinematic mediations and meditations on the Philippine-American contact, drawing more attention to the metamediation of (re)constructed memories of a neglected past.

Laurence Marvin S. Castillo's “The Primitive-Indigenous-Oriental as the Horrific Abject in Chito Roño's Horror-Film Trilogy" illustrates how 
filmmaker Chito Roño's vision of cinematic horror is a tableau that dramatizes a muddled and marginalized Filipino culture as a result of many centuries of colonization. Using Kristeva's notion of "the abject" vis-à-vis Tamborini and Weaver's horror categories, Castillo positions Roño's horror trilogyFeng Shui (2004), Sukob (2006), and T2 (2009) - as an exploration into the abjection of the Filipino consciousness. Meanwhile, Alvin B. Yapan's "Ang Kaalamang-Bayan sa Penomenon ng Sapi sa mga Pelikulang Katatakutan" is a suitable partner piece to Castillo's essay. Yapan's work is an attempt to contextualize the nature and narrative of possession or sapi in the realm of the ordinary and the commonplace in several horror texts. Using an episode from the 1980s TV show Lovingly Yours, Helen, "Akin ang Walang Diyos" starring Julie Vega, and three films-namely, Gumising Ka, Maruja (1978), Haplos, and Patayin Mo sa Sindak si Barbara-the essay demonstrates the nonexistence of a bridge that connects reality with fantasy, between real life and cinema.

"On Film and Reflexivity: Specters of Truth in Some Films-within-Films" by Louise Jashil R. Sonido examines ten Filipino films that demonstrate Derrida's notion of "spectralization," the phantasmic nature of the image in media. The chosen films may all be described as reflexive, from Ishmael Bernal's subtle jab at the commercial and the exploitative aspects of filmmaking in Pagdating sa Dulo, to Mike de Leon's critical look into the challenges of filming Rizal's contested heroism in Bayaning Third World, to Chris Martinez's take on "poverty porn" in Ang Babae sa Septic Tank. Using Foucault's ideas of discourse and power alongside Derrida's spectralization, Sonido provides an erudite discussion of the varied versions of truth that are created in the ten films.

Nestor O. Jardin's “The Cinemalaya Philippine Independent Film Festival" gives the reader an overview of Cinemalaya's beginnings as a festival, its mission, and its achievements. It also provides appendices that showcase in detail the milestones, festival statistics, film titles, and filmmakers that Cinemalaya has featured since its inception. Vicente G. Groyon's "Cinemarehiyon 2009" is a look at the film festival during its first year, and attempts to articulate the difficulties involved in the curatorial practices in selecting "regional" films for exhibition.

In "Two Indie Films on Human Trafficking," Rosalie Matilac critiques the films Halaw by Sheron Dayoc and Donor by Mark Meily. Using Armando Lao's concepts of the found story and found-time treatment in filmmaking, Matilac argues that both films are inadequate in illuminating the complexities of human trafficking, with Halaw failing to utilize the context of history and the "sense of place" of its characters, and Donor falling into the trap of misogyny and formulaic characterization. Moreover, the latter 
film's insensitivity in its display of onscreen poverty, according to Matilac, prevents it from having a liberating stance despite its technical mastery.

For a festschrift, the book is quite slim, though not wanting in terms of depth and diversity. The book is intelligently written and scholarly in its tone and approach. It offers a complex portrait of a national cinema that has been written about, all too frequently, from a macro perspective. The cinema that emerges from the readings is one that is alive, flourishing, and teeming with issues that result from the varied concerns of Filipino film scholars in the twenty-first century. Perhaps because the book is mainly a collection of papers presented at the 2011 symposium, the reader might want greater cohesiveness; each chapter remains quite distinct from the others, without much of a thread unifying the entire collection. This is, however, nitpicking, since the assortment of essays create a stimulating randomness to the seemingly static subject matter that is Philippine cinema.

Another quibble with a book that talks about Philippine cinema is the inconsistency in the selection and analysis of the chosen texts in some of the essays. Yapan's essay, for instance, uses a TV episode in his discussion. There is also unevenness in the treatment of the texts, as seen in the analysis of Patayin Mo sa Sindak si Barbara, particularly toward the end of the essay. It seems to be an afterthought, a mere postscript to further the essay's last point about memory and forgetting. Some essays succeed in their attention to specifics. In Castillo's essay, for example, he proposes the abjectification of the primitive, the indigenous, and the Oriental in the horror films he studied. Castillo argues that Roño's idea of horror is not so much the continual emergence of the abject Other, nor the surfacing and resurfacing of the repressed primitive that threatens the existing order, but the realization that we, as Filipinos, have become the abject Other, that the Filipino viewers have been "alienated from and terrorized by their own indigenous culture" (Chua et al., p. 108) through horror. We have become the horrific abject that provokes our own revulsion and dread. We are our own monsters.

Giving attention to the technical aspects of filmmaking is also one of the book's achievements. Pamintuan's attention to sound, like Del Mundo's take on cinematography and the authorship of Lacap as the carrier of cinematic meanings, is effective in its attempt to recognize one of the not-so common facets of film criticism in the Philippines. Pamintuan explores how sound and music serve a function in our understanding, not just of character, but also of the external forces that affect the characters we are being asked to empathize with. Sound design in movies, in relation to the other elements of film, carries the socio-cultural meanings contained by the narrative, and in the essay's three chosen films, it is the sound of metal that bridges 
the main characters effectively with the audience, as the latter absorbs the identities onscreen as something we have heard and witnessed all our lives. What we hear in the movies is what we hear when we ourselves walk along the streets of the decaying urban city. The sound of decay is the soundtrack of our lives.

A Reader in Philippine Film has much to offer. Many of the subjects treated in the book have not been given extensive treatment elsewhere; for instance, Groyon's take on the problem inherent in the "regional" category in Cinemarehiyon, and how this forced classification "fails to account for authorial matters such as heritage, mobility and migration, thematic concerns or preferences, collaboration, and aesthetic freedom" (p. 195). The analysis of several films and filmmakers in the book will also help guide readers, whether scholars or film enthusiasts, toward an enhanced appreciation of Philippine cinema with all the concerns of the new century. The collection's grounded look at cinema in relation to literature, authorship and creativity, and the colonial aesthetics apparent in Philippine films evoke the honoree's lifelong commitment to art in general and to cinema in particular.

Alongside the main goal of the book, which is to write a diverse assembly of thoughts about Philippine cinema, is the task of honoring Nicanor G. Tiongson, and to read, via the collected essays, Tiongson's signature, locating his very mark in relation to Philippine cinema. In this regard, the book succeeds in showing, albeit subtly, how Tiongson has influenced and inspired many film scholars in the county, giving the reader a stimulating look at the man being honored. The Tiongson that surfaces is, like Philippine cinema, one who is extremely varied, as specific and as detailed, as complex and as contemporary, as the issues that continue to shape our national films. 


\section{Reference}

Chua, J., Rosario, C. L., \& Tolentino, R. B. (Eds.). (2014). A reader in Philippine film: history and criticism.

Quezon City: University of Philippines Press.

ANNE FRANCES N. SANGIL is a full time Assistant Professor at De La Salle University Department of Literature, where she teaches art appreciation, Philippine literature, popular culture, and a literature elective on J.K. Rowling. She is a member of Popular Culture Association and was also a Writing Fellow for Film Studies at the Bienvenido N. Santos Creative Writing Center of DLSU-Manila. She is currently writing her dissertation for a PhD in Literature (corresponding author: anne.sangil@dlsu.edu.ph). 